\title{
Stanowisko do automatycznego napawania płyt stalowych
}

\section{The station of the automatic pad welding of steel plates}

\section{Streszczenie}

Wiele maszyn i urządzeń technicznych, szczególnie, eksploatowanych w przemyśle wydobywczym lub budownictwie, narażonych jest na intensywne zużycie powierzchni roboczych w wyniku ścierania. Wydłużenie czasu ich eksploatacji wymaga wytworzenia na ich powierzchniach warstw odpornych na ścieranie. Najlepszą metodą wytwarzania takich warstw jest napawanie stosowane zarówno w procesie wytwarzania, jak i regeneracji części zużytych.

W artykule przedstawiono stanowisko do automatycznego napawania płyt stalowych o maksymalnych wymiarach $1500 \times 3000 \mathrm{~mm}$. Wytwarzano warstwy o twardości ok. $60 \mathrm{HRC}$ i dużej odporności na ścieranie. Omówiono budowę i charakterystykę techniczną stanowiska oraz wybrane aspekty technologii napawania.

\section{Wstęp}

Wiele maszyn i urządzeń technicznych, szczególnie tych eksploatowanych w przemyśle wydobywczym lub budownictwie, narażonych jest na intensywne zużycie powierzchni roboczych w wyniku ścierania [3]. Wydłużenie czasu ich eksploatacji wymaga wytworzenia na ich powierzchniach warstw odpornych na ścieranie. Najlepszą metodą wytwarzania takich warstw jest napawanie, stosowane zarówno w procesie wytwarzania, jak i regeneracji części zużytych $[1,3,5]$.

W artykule przedstawiono autorskie stanowisko do automatycznego napawania płyt stalowych, na którym wytwarzane są warstwy stopowe o twardości ok. 60 HRC, położone na niskowęglowej stali konstrukcyjnej.

Dr inż. Tadeusz Sarnowski - ZAP Robotyka, Ostrów Wielkopolski, dr inż. Pawel Cegielski, dr hab. inż. Andrzej Kolasa, prof. PW - Politechnika Warszawska.
Artykuł zawiera opis budowy i charakterystykę techniczną stanowiska oraz wybrane aspekty technologii napawania. Schemat stanowiska przedstawiono na rysunku 1.

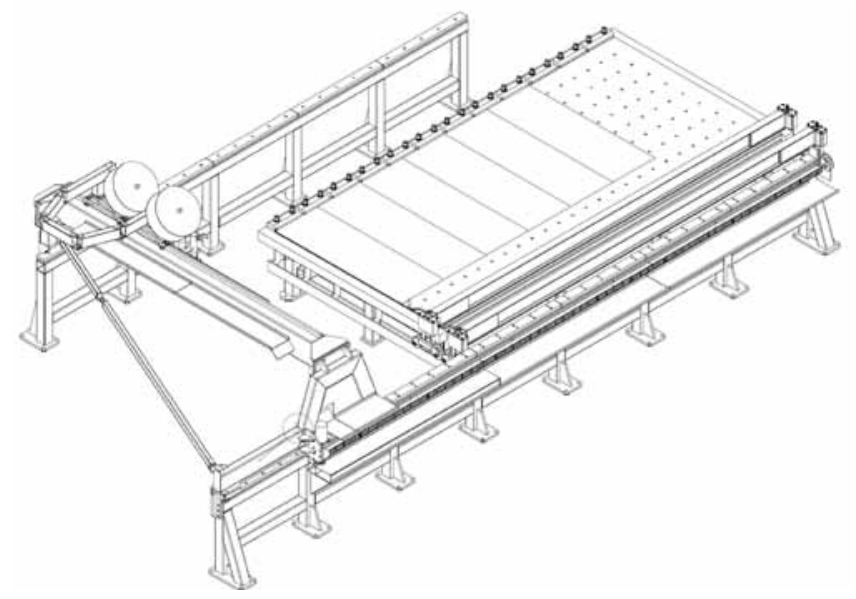

Rys. 1. Schemat stanowiska do napawania płyt Fig. 1. Station of pad welding of plate scheme 


\section{Konfiguracja stanowiska}

Stanowisko składa się z następujących urządzeń:

- Stołu o wymiarach 2000x4000 mm, na którym umieszcza się płytę, na którą nakładana jest warstwa napawana. Płyta zostaje umieszczona na stole za pomocą suwnicy. W konstrukcji stołu znajduje się system chłodzenia wodnego. Dodatkowo, ułatwiono dostęp do całej powierzchni stołu dzięki zastosowaniu miejsca parkingowego dla konstrukcji jezdnej.

- Manipulatora (konstrukcji jezdnej) z programowanym przemieszczaniem $w$ osi $X$ i $Y$, wyposażonego w systemy napędowe, w skład których wchodzą serwomotory, precyzyjne prowadnice oraz dokładne listwy zębate, zapewniające wysoką precyzję pozycjonowania oraz długą żywotność urządzenia.

- Zespołu urządzeń spawalniczych składającego się z dwóch źródeł zasilania MIG/MAG z podajnikami drutu elektrodowego. Podajniki wraz z uchwytami spawalniczymi przesuwają się liniowo wzdłuż toru jezdnego $w$ osi $X$ oraz ruchem poprzecznym w osi Y. Uchwyty spawalnicze zamocowane są w sposób umożliwiający regulację odległości końcówki spawalniczej od napawanej blachy.

Stanowisko do napawania płyt przedstawiono na rysunku 2.

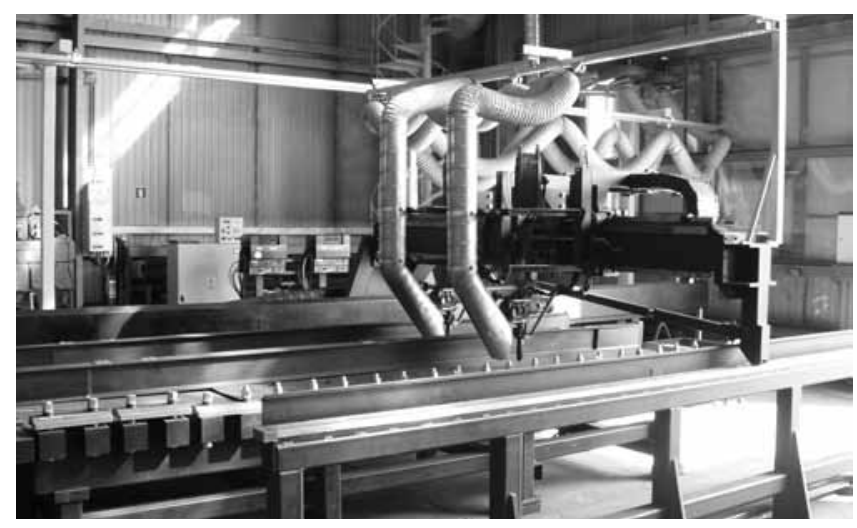

Rys. 2. Stanowisko do napawania płyt

Fig. 2. Station of pad welding of plates

\section{Manipulator}

Manipulator zawiera dwie sterowane automatycznie osie X i Y (ruchy równoległe do powierzchni napawanej płyty) oraz oś $Z$ (podnoszenie uchwytów elektrodowych) sterowaną ręcznie. Oś $Y$ wyposażona jest $w$ dwa wózki jezdne, każdy obsługujący uchwyt spawalniczy $i$ kasetę $z$ drutem elektrodowym. Przesuw osi X i Y jest w pełni programowalny. Obydwa napędy wykorzystują serwonapędy Rexroth Bosch Group i odpowiednie przekładnie [6]. Maksymalna prędkość przesuwu osi $X$ i Y wynosi $5000 \mathrm{~mm} / \mathrm{min}$. Ręczna regulacja odległości końcówki uchwytu spawalniczego od napawanej blachy odbywa się w zakresie $0 \div 100 \mathrm{~mm}$. Regulacja odległości pomiędzy uchwytami spawalniczymi jest ręczna, w zakresie 45 $\div 750 \mathrm{~mm}$.

\section{Układ sterowania}

Układ sterowania umieszczono w szafie sterowniczej. Wewnątrz szafy znajduje się zasilacz, sterownik PLC L20, dwa sterowniki mocy IndraDrive, zestaw przekaźników i styczników [6]. Na szafie umieszczono pulpit sterowniczy z panelem operatorskim VCP05. Sterownik jest zasilany napięciem $24 \mathrm{~V}$ DC. Jest on standardowo wyposażony w 8 wejść i 8 wyjść cyfrowych, Profibus DP, Ethernet i RS 232. Dodatkowo zainstalowano po 2 moduły 16 wejść i 16 wyjść cyfrowych. Sterowniki IndraDrive obsługiwane są przez PLC poprzez magistralę Profibus, a panel operatorski z PLC przez Ethernet.

\section{Panel operatorski}

Panel VCP05 ma ekran o rozdzielczości $160 \times 80$ oraz zestaw przycisków sterujących. Oznaczenie i funkcje większości przycisków są zgodne z klawiaturą komputerową (rys. 3).

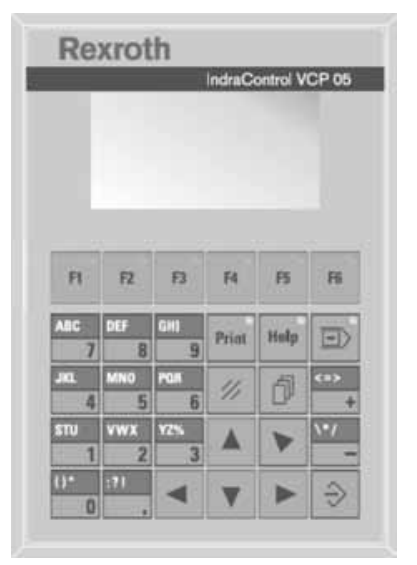

Rys. 3. Panel operatorski VCP 05 Fig. 3. Control panel VCP 05

\section{Tryb pracy ze sterowaniem ręcznym}

W trybie ręcznym można poruszać obiema programowalnymi osiami manipulatora. Maksymalna prędkość ruchu ręcznego wynosi $5000 \mathrm{~mm} / \mathrm{min}$. Wartość odniesienia jest stała, przy czym dla kolejnych instrukcji opisujących ruch w czasie programowania należy zastosować odpowiedni współczynnik procentowy prędkości z zakresu $1 \div 100 \%$. I tak, dla nastawy $10 \%$ ruch będzie się odbywał z prędkością $500 \mathrm{~mm} / \mathrm{min}$.

W osi $X$ aktywne są przyciski:

F2 - ruch do przodu,

F3 - ruch do tyłu.

W osi Y aktywne są przyciski:

F5 - ruch w lewo,

F6 - ruch w prawo.

W celu zwiększenia bezpieczeństwa i zapewnienia ruchu bezkolizyjnego wprowadzono ograniczenia programowe. Przekroczenie ich wartości uniemożliwia dalszy ruch w danym kierunku i powoduje wygenerowanie sygnału odpowiedniego błędu. 


\section{Tryb pracy ze sterowaniem automatycznym}

W trybie pracy automatycznej manipulator rozpoczyna napawanie blach wg parametrów wybranych przez operatora, tj. rodzaju płyty, prędkości napawania oraz rodzaju warstwy napawanej (1 lub 2). Kierunki ruchu manipulatora przedstawiono na rysunku 4.

Cykl pracy dla warstwy 2 (licowej) polega na wykonaniu przez manipulator określonej liczby ściegów o tej samej szerokości, przy zadanej prędkości napawania. Parametry prądowo-napięciowe napawania blach oraz prędkości ustawiane są przez użytkownika. Cykl pracy dla warstwy 1 (podkładowej) polega na wykonaniu z użyciem manipulatora określonej liczby ściegów, która jest mniejsza o jeden od liczby ściegów warstwy 2. Dla warstwy 1 ściegi nie mają takiej samej szerokości. Pierwszy oraz ostatni ścieg mają szerokość o $50 \%$ większą. Programy układania ściegów $w$ warstwie 1 i 2 są tak napisane, aby dla obu warstw wzajemnie na siebie zachodziły (rys. 5).

Działanie programu pracy w cyklu automatycznym polega na tym, że po skończeniu napawania połowy blachy manipulator przerywa pracę i przesuwa się do pozycji Home. Dzieje się tak ze względu na niezbędną zmianę położenia belek przytrzymujących napawaną blachę. Aby kontynuować pracę po zmianie położenia belek, należy wcisnąć przycisk "Początek cyklu” na panelu operatorskim. Istnieje również możliwość wpisania nowych wartości początkowych, w celu rozpoczęcia cyklu pracy $z$ dowolnego miejsca na powierzchni

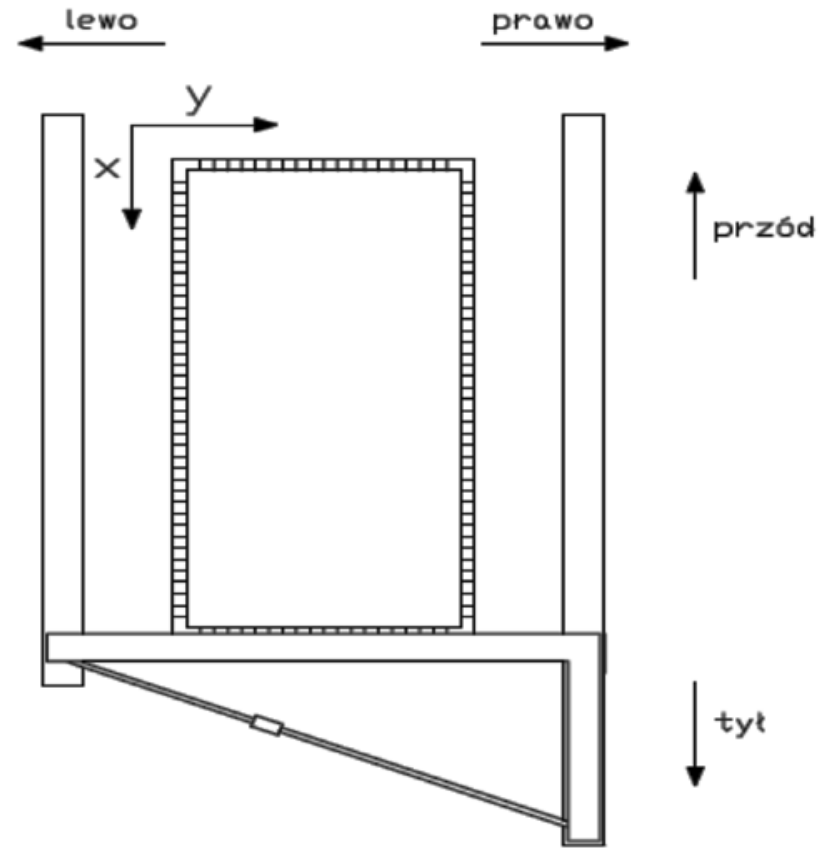

Rys. 4. Kierunki ruchu manipulatora

Fig. 4. The manipulator moving directions

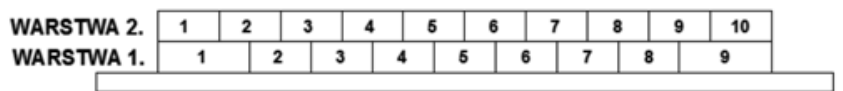

Rys. 5. Rozkład ściegów w warstwach

Fig. 5. Bead distribution in the layers

blachy. Wtedy na ekranie głównym należy wybrać polecenie „Kontynuacja”, a następnie wpisać odpowiednie wartości początkowe.

\section{Cykl roboczy stanowiska}

Stanowisko pracuje w cyklu automatycznym, realizując założony program. Napawanie odbywa się równocześnie dwoma urządzeniami spawalniczymi, z możliwością realizacji ruchu oscylacyjnego. Płyta przeznaczona do napawania jest ładowana na stół za pomocą suwnicy i mocowana do stołu za pomocą specjalnych ręcznych uchwytów mocujących. Przygotowanie urządzenia do cyklu automatycznego wymaga wprowadzenia wszystkich parametrów technologicznych, w tym związanych z geometrią napawania (rys. 6). Ich zmiana lub dodanie nowych parametrów realizowane jest na ekranie głównym przez odpowiednie polecenie. Można także ustawić pozycję Home, do której ma dojeżdżać manipulator, ustawić prędkości napawania obydwu warstw oraz wybrać dla niej rodzaj warstwy (szybko - warstwa 1, wolno - warstwa 2), ustawić czasy włączenia i wyłączenia napawania, a także wybrać rodzaj blachy, która będzie napawana.

Zmiana szerokości ściegu realizowana jest przez zmianę parametru SZER, natomiast parametr ODSTĘP jest stały i określony dla każdej blachy z osobna. Kolejnym etapem jest ustawienie odległości między uchwytami elektrodowymi oraz ustawienie belek przytrzymujących płyty. Po wyborze programu rozpoczyna się automatyczny cykl pracy stanowiska - napawanie. Po zakończeniu procesu portal przejeżdża w miejsce parkingowe, a pracownik odmocowuje płytę i z użyciem suwnicy odkłada ją w miejsce składowania.

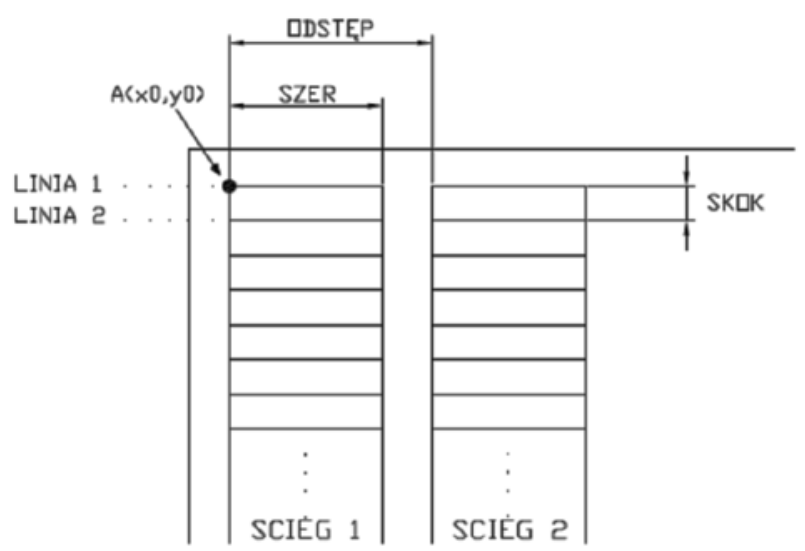

Rys. 6. Parametry geometryczne napawania blach

Fig. 6. Geometrical parameters of pad welding of plates 


\section{Technologia napawania}

Napawanie wykonywane jest drutem samoosłonowym DPIS-61 $\varnothing 3,2 \mathrm{~mm}$. Grubość napoiny wynosi $4 \div 6 \mathrm{~mm}$, a liczba programowanych warstw $1 \div 3$. Uzyskiwana twardość napoiny to $55 \div 65 \mathrm{HRC}$. Szerokość oscylacji jest regulowana na drodze programowania. Ustalono, w wyniku wielu prób technologicznych, amplitudę oscylacji w przedziale: $37 \div 39 \mathrm{~mm}$.

\section{Efekty zastosowania stanowiska}

Stanowisko, w porównaniu z tradycyjnymi metodami napawania, wyróżnia się:

- poprawą jakości napoin,

- wzrostem wydajności,

- poprawą organizacji i warunków pracy.

\section{Literatura}

[1] Cary B. H.: Modern welding technology, Regents/Prentice Hall, New Jersey 1994.

[2] Dobaj E.: Maszyny i urządzenia spawalnicze, Warszawa, WNT 2005.

[3] Klimpel A.: Napawanie i natryskiwanie cieplne. WNT, Warszawa 2000.
[4] Praca zbiorowa pod red. K Ferenca: Technika spawalnicza w praktyce. Poradnik inżyniera konstruktora i technologa. Verlag Dashofer, Warszawa 2007-2011 (cykl wydawniczy).

[5] Praca zbiorowa: Poradnik inżyniera. Spawalnictwo. T. 1 i 2. WNT, Warszawa 2003 i 2005.

[6] Dokumentacje zastosowanych sterowników i serwonapędów Rexroth Bosch Group.

\section{Nowości techniczne}

\section{Systemy ochronne Versaflo ${ }^{\mathrm{TM}}$ od $3 \mathrm{M}$ - złap w pracy głębszy oddech}

Z myślą o osobach pracujących w przemyśle firma $3 \mathrm{M}$ Poland wprowadza Versaflo ${ }^{\mathrm{TM}}$ - uniwersalną gamę systemów ochrony dróg oddechowych. Uproszczony dobór sprzętu, wyższy komfort użytkowania oraz większa uniwersalność zastosowań sprawiają, że nowa seria produktów 3M doskonale sprawdza się m.in. w farmacji, przemyśle drzewnym, i hutnictwie.

Każdy system ochrony dróg oddechowych Versaflo ${ }^{\mathrm{TM}}$ składa się z trzech elementów: nagłowia, węża oddechowego i jednostki napędowej lub aparatu wężowego. Wszystkie części są kompatybilne, dzięki czemu użytkownik może je dowolnie dobierać i zestawiać przy przejściu z jednego środowiska do innego. W porównaniu do półmasek i masek z wymiennymi elementami oczyszczającymi, systemy Versaflo ${ }^{\mathrm{TM}}$ znacznie zmniejszają ucisk na twarz i uczucie gorąca, zapewniając swobodę oddychania oraz większy komfort pracy.

Systemy ochronne Versaflo ${ }^{\mathrm{TM}}$ opracowano, w celu zwiększania bezpieczeństwo pracy osób narażonych na działanie pyłów, dymów, gazu czy pary. Powietrze do nagłowia dostarczane jest automatycznie, bez wysiłku związany z oddychaniem w maskach i półmaskach. Ponadto, system $3 \mathrm{M}$ jest odporny na chemikalia i porysowanie. Z tego względu może być z powodzeniem wykorzystywany we wszystkich gałęziach przemysłu - mówi Marta Kapała, z Bezpieczeństwa Pracy w 3M Poland.

Seria systemów Versaflo ${ }^{\mathrm{TM}}$ oferuje szeroki zakres produktów - od lekkich kapturów po hełmy przemysłowe zapewniające nie tylko ochronę dróg oddechowych, ale także oczu, twarzy i słuchu. Nagłowia (serii M) mogą być stosowane $z$ okularami korekcyjnymi lub ochronnymi. Modele M-100 i M-300 mają także możliwość dołączenia nauszników 3M ${ }^{\mathrm{TM}}$ Peltor $^{\mathrm{TM}}$. Natomiast kaptury serii S zapewniają ochronę oczu i twarzy przed rozbryzgami cieczy i uderzeniami cząstek o niskiej energii (zgodnie z normą EN166). Powłoki zabezpieczające na szybach zapewniają dodatkową ochronę przed chemikaliami i porysowaniem.

Węże oddechowe Versaflo ${ }^{\mathrm{TM}} \mathrm{BT}-30 \mathrm{z}$ funkcją samodopasowania długości umożliwiają ich przystosowanie w zależności od wzrostu użytkownika. Pozwala to uniknąć przypadkowego zaczepienia węża o wystające elementy. Innowacyjne połączenie QRS umożliwia połączenie i rozłączenie przy użyciu tylko jednej ręki, a jego obrotowe działanie zmniejsza możliwość zapętlania i załamywania się węża oddechowego.

Jako uzupełnienie systemu Versaflo ${ }^{\mathrm{TM}}$ firma $3 \mathrm{M}$ oferuje do wyboru dwa systemy z wymuszonym przepływem powietrza - jednostki napędowe TR-300 i Jupiter ${ }^{\mathrm{TM}}$ - oraz trzy aparaty wężowe $z$ doprowadzeniem powietrza (seria V). Lekkie jednostki napędowe przylegają płasko do pleców użytkownika, zmniejszając efekt dźwigni i ograniczając wrażenie ciężkości. Ich kompaktowy kształt umożliwia również pracę w pozycji siedzącej bez ograniczania dopływu powietrza do systemu. Filtry zasadnicze i wstępne mogą być łatwo i szybko wymienione bez użycia narzędzi.

Magdalena Słodownik Tomasz Gołębiewski 